\title{
Brachyterapia mięsaków tkanek miękkich w lokalizacji uro-genitalnej u dzieci w świetle doniesień konferencji ESTRO35.
}

\section{Brachytherapy of soft tissue sarcomas in uro-genital location in children in the light of the ESTRO35 conference.}

\author{
Artur Chyrek ${ }^{1}$ \\ ${ }^{1}$ Zakład Brachyterapii Wielkopolskie Centrum Onkologii, Wielkopolskie Centrum Onkologii, Poznań, Polska
}

\section{Streszczenie}

Wiosną 2016 roku w Turynie we Włoszech odbyła się kolejna, 35 konferencja naukowa Europejskiego Towarzystwa Radioterapii Onkologicznej (ESTRO). W jej trakcie prezentowany był panel grupy GECESTRO zajmującej się brachyterapią - metodą radioterapii polegającą na bezpośrednim wprowadzeniu izotopu promieniotwórczego w guza lub jego lożę. Artykuł ten ma na celu prezentację doniesień dotyczących brachyterapii mięsaków tkanek miękkich wieku dziecięcego-leczenia, które niesie ze sobą wiele potencjalnych korzyści dla pacjentów pediatrycznych, a nie jest niestety dostępne w Polsce.

\begin{abstract}
The 35th scientific conference of the European Society of Radiation Oncology (ESTRO) took place in the spring of 2016 in Turin, Italy,. The session included a panel of GEC-ESTRO group on brachytherapy a method of radiotherapy involving the direct introduction of a radioisotope into the tumor, its surroundings or a tumor bed. This brief article aims at presenting reports on brachytherary of pediatric soft tissue sarcomas - a treatment that has many potential benefits for pediatric patients but is, unfortunately, not available in Poland.
\end{abstract}

Słowa kluczowe: brachyterapia , onkologia dziecięca, mięsaki tkanek miękkich

Keywords: brachytherapy, pediatric oncology, soft tissue sarcomas

Adres do korespondencji

Artur Chyrek

Zakład Brachyterapii Wielkopolskie Centrum Onkologii

Wielkopolskie Centrum Onkologii, ul. Garbary 15, 61-866 Poznań, Polska

Telefon. +4861885 o 817

e-mail: artur.chyrek@wcp.pl 


\section{Wstęp}

Nowotwory wieku dziecięcego stanowią w krajach rozwiniętych około 1\% wszystkich nowotworów złośliwych i są drugą przyczyną śmierci w grupie wiekowej 1-14 lat ( po wypadkach i urazach) [1]. Mięsaki tkanek miękkich (MTM) są piątą co do częstości występowania grupą nowotworów u dzieci po białaczkach, guzach OUN, chłoniakach i nerwiaku zarodkowym ze wskaźnikiem zachorowalności na poziomie $0,2-1,0 / 100000$ rocznie ( około $7 \%$ z wszystkich nowotworów pediatrycznych ), wywodzącą się z komórek embrionalnej tkanki mezenchymalnej i neuroektodermalnej [2] . Stanowią one heterogenną grupę nowotworów zarówno pod względem histopatologii jak i lokalizacji guza pierwotnego, a obie te zmienne wraz z doszczętnością zabiegu operacyjnego oraz pierwotnym zaawansowaniem wg klasyfikacji TNM kwalifikują młodego pacjenta do odpowiednich stopni i grup rokowniczych warunkujących zaplanowanie odpowiedniego leczenia interdyscyplinarnego, na które składa się chirurgia, chemioterapia oraz radioterapia[2,3]. Pomimo braku randomizowanych badań klinicznych 3 fazy porównujących brachyterapię (BT) z klasyczną teleradioterapią (EBRT) w leczeniu MTM u dzieci i młodzieży stosowanie BT jest jak najbardziej uzasadnione gdyż pozwala dostarczyć wyższą niż przy pomocy EBRT dawkę promieniowania do ściśle określonej objętości i jednocześnie daje możliwość redukcji promieniowania w tkankach zdrowych, zmniejszając tym samym ryzyko późnych powikłań popromiennych - co tak ważne jest w przypadku leczenia nowotworów u dzieci [1]. Z tego powodu BT stosowana jest zarówno jako metoda samodzielnej radioterapii uzupełniającej jak i w skojarzeniu z EBRT, a główne lokalizacje MTM dziecięcych, w których stosuje się tę metodę to lokalizacje uro-genitalne [4]. Właśnie tych umiejscowień MTM dotyczyły doniesienia prezentowane na konferencji ESTRO 35.

\section{- MTM w lokalizacjach ginekologicznych}

Nowotwory kobiecego narządu płciowego w okresie dzieciństwa są rzadkie, ale również trwale wyleczalne - zabiegi oszczędzające obejmujące różne kombinacje metod leczenia onkologicznego prowadzą do 5-letnich wskaźników przeżycia $>90 \%$ [5]. Badacze z francuskiego ośrodka Gustave Roussy, który przoduje w brachyterapii pediatrycznej w Europie, zaprezentowali ważną w kontekście tak dużego odsetka wyleczeń pracę dotyczącą późnych powikłań występujących po leczeniu[6] . Badanie dotyczyło 42 pacjentek (mediana wieku 1,7 roku) leczonych w latach 1971 - 2004 z czego u 30 rozpoznano MTM - głównie mięsaki prążkowanokomórkowe (rhabdomyosarcoma - RMS) (29 p.) , u pozostałych 12 rozpoznano nowotwory zarodkowe lub gruczolakoraki jasnokomórkowe . 88\% pacjentek otrzymało chemioterapię, 31\% wymagało operacji chirurgicznej, natomiast wszystkie chore leczone były za pomocą uzupełniającej brachyterapii LDR (o niskiej mocy dawki ) śródjamowej (69\%), śródtkankowej (14\%) lub połączeniem obu (17\%). Mediana dawki wynosiła 60 Gy (10-80 Gy), 2 chore otrzymały leczenie skojarzone z EBRT, a 36 miało wykonaną transpozycję jajników przed rozpoczęciem napromieniania. Przeżycie całkowite w tej grupie wynosiło $98 \%$ (jedna pacjentka zmarła z powodu drugiego nowotworu - leiomyosarcomy macicy), kontrola miejscowa 94\% (dwie wznowy miejscowe) przy medianie obserwacji 15,5 roku. Badanie powikłań opierało się na badaniach przedmiotowych w trakcie obserwacji (ocena wg klasyfikacji CTCAE v4) oraz na ankietach składających się z systemu punktowego LENT SOMA oraz kwestionariuszy SF-36v2 dotyczących dróg rodnych, układu moczowego, układu pokarmowego, jakości życia oraz sfery seksualnej (ostatni kwestionariusz pomijany u nieletnich), które zostały wypełnione przez 51\% pacjentek. Łącznie odnotowano 160 różnych powikłań późnych u 32 (76\%) pacjentek, 115 z nich (72\%) wystąpiło w stopniach G1-2, 45 (28\%) G3-4 (włączając do tej grupy jedno powikłanie G5: zgon z powodu drugiego nowotworu). 10 pacjentek (22.7\%) nie prezentowało żadnych efektów późnych przebytej terapii, 5 miało jedynie toksyczność późną G1-2 , a 19 chociaż jedno powikłanie w stopniu 3. Najczęściej występowały powikłania ginekologiczne - 75/160 (47\%) , które dotyczyły 28 (67\%) chorych (zwężenia pochwy, przewlekły ból w miednicy, metrorrhagia, przetoki, suchość pochwy) oraz powikłania z układu moczowego - 54/160 (34\%) u 19 osób (45\%). Łącznie 16 pacjentek (38\%) wymagało interwencji chirurgicznej ze względu na powikłania w stopniu G3-4 . Najczęstszym zabiegiem była rekonstrukcja pochwy z powodu zwężenia $(n=9)$, operacje stenozy moczowodu $(n=5)$ i cewki moczowej $(n=4)$, i zabiegi naprawcze przetok pochwowych $(n=4)$.

Regularną aktywność seksualną zadeklarowało 12 z 14 pacjentek,, które wypełniły ankietę, a 4 z nich urodziły zdrowe potomstwo. Tylko 2 pacjentki z 21 oceniły jakość życia jako złą.

W analizach statystycznych jedno i wieloczynnikowych nie znaleziono czynników prognostycznych zwiększających prawdopodobieństwa wystąpienia powikłań w stopniu 3 i wyższych, zauważono jednak, iż większa ilość tychże obserwowana była u chorych leczonych przed rokiem 1990 co korelowało z większą objętością leczona $(>11 \mathrm{~cm} 3)$ 
oraz większą dawką podaną (>60Gy). Na podstawie tych obserwacji autorzy wysunęli wnioski, iż dalszy postęp technologiczny wiążący się z lepszym obrazowaniem i opartym na nim planowaniem może być kluczowy dla dalszego zwiększania skuteczności brachyterapii i zmniejszania częstości powikłań w leczeniu mięsaków tej okolicy.

\section{- MTM okolicy pęcherza moczowego i prostaty}

Nowotwory tej lokalizacji u dzieci to także w zdecydowanej większości mięsaki prążkowanokomórkowe (rhabdomyosarcoma - RMS). Guzy tej okolicy są również bardzo rzadkie, gdyż stanowią raptem 11\% wszystkich RMS w populacji pediatrycznej[7]. Badanie dotyczące leczenia mięsaków tej okolicy prezentowane w Turynie to także praca z francuskiego ośrodka Gustave Roussy. Było to pierwsze doniesienie ustne prezentujące dużą grupę 100 pacjentów leczonych w latach 1991-2015, mające ukazać się w literaturze medycznej dopiero po ponad roku [8]. Wszystkie dzieci (88 chłopców i 12 dziewczynek, mediana wieku 28 miesięcy) leczone były w pierwszej kolejności chemioterapią, a następnie wykonywano oszczędzający zabieg chirurgiczny z jednoczesnym założeniem śródtkankowym aplikatorów do BT (oraz reimplantacją moczowodów u 63\% chorych). 5\% otrzymało BT jako tzw. boost w dawce 20-30 Gy (podwyższenie dawki) przed planowaną EBRT 30-45 Gy ze względu na zajęcie węzłów chłonnych miednicy lub rozsiew do otrzewnej, pozostała część otrzymała radioterapię wyłącznie przy użyci BT do dawki 4565 Gy (mediana 60 Gy). Dla 4\% było to leczenie nawrotu miejscowego guza, a 12\% miało przerzuty odległe przed leczeniem. Szacowane 5-letnie przeżycie wolne od choroby (DFS) wyniosło 84\% - łącznie w całej grupie wystąpiło 12 wznów choroby (6 miejscowych, 1 odległa, 5 miejscowych i odległych jednocześnie). W grupie, która otrzymała wyłącznie brachyterapię wystąpiło, natomiast 5-letnie przeżycie całkowite (OS) określone zostało na poziomie 91\% (6 pacjentów zmarło z powodu leczonego nowotworu) przy medianie czasu obserwacji 64 miesiące. Spośród wielu badanych zmiennych statystycznie istotny wpływ na gorsze DFS miała pierwotna wielkość guza podczas diagnozy przekraczająca w największym wymiarze $5 \mathrm{~cm}$. Podczas obserwacji pacjentów bez wznowy powikłania wymagające interwencji endoskopowej lub chirurgicznej wystąpiły jedynie u 14 pacjentów (15.1\%), z czego tylko u 3 z nich konieczna była cystektomia ze względu na niefunkcjonalny pęcherz moczowy. Aż 78\% pacjentów podczas ostatniej kontroli zadeklarowało prawidłowe trzymanie moczu. Doniesienie to, które jest oparte jak do tej pory na największej grupie pacjentów pediatrycznych leczonych brachyterapią pokazuje, iż ścisła współpraca chirurgów oraz specjalistów radioterapii zabiegowej daje świetne efekty u dobrze wyselekcjonowanych pacjentów z RMS okolicy prostaty/pęcherza w postaci wysokiej kontroli nowotworu oraz znacznej minimalizacji odległych powikłań z układu moczowego.

\section{Konflikt interesu / Conflict of interest}

Nie występuje / None

\section{Finansowanie / Financial support}

Praca finansowana w ramach grantu wewnętrznego Wielkopolskiego Centrum Onkologii nr 4/2016 (119)

\section{Etyka / Ethics}

Treści przedstawione w artykule są zgodne z zasadami Deklaracji Helsińskiej, dyrektywami EU oraz ujednoliconymi wymaganiami dla czasopism biomedycznych.

\section{Piśmiennictwo / References}

[1] Gerbaulet A, Pötter R. Paediatric Malignancies; GEC-ESTRO Handbook Paediatric Malignancies (2002)

[2] Bernarda Kazanowska, Alicja Chybicka ,'Nowotwory tkanek miękkich - Zalecenia postępowania diagnostyczno-terapeutycznego w nowotworach złośliwych - 2011 r."

[3] CWS-2006. A guidance for risk adapted treatment of soft tissue sarcoma in children, adolescents and young adults, version 1.3.

[4] Fijuth J. Brachytherapy in paediatric malignancies - review of indications; J Contemp Brachytherapy. 
2010 Jun; 2(2): 81-83.

[5] Magné N. and Haie-Meder C. Brachytherapy for genital-tract rhabdomyosarcomas in girls: technical aspects, reports, and perspectives. Lancet Oncol. 2007; 8: 725-72

[6] Levy A, Martelli $\mathrm{H}$ et al. Late toxicity of brachytherapy after female genital tract tumors treated during childhood: Prospective evaluation with a long-term follow-up. Radiotherapy and Oncology, Vol. 117, Issue 2, p206-212

[7] McDowell HP. Update on childhood rhabdomyosarcoma. Arch Dis Child 2003;88:354-7

[8] Chargari C, Haie-Meder C, Brachytherapy Combined With Surgery for Conservative Treatment of Children With Bladder Neck and/or Prostate Rhabdomyosarcoma. Int J Radiat Oncol Biol Phys. 2017 Jun 1;98(2): 